\title{
Influence of Emotional Intelligence on the Workforce for Industry 5.0
}

\author{
Susan Tee Suan CHIN \\ Multimedia University, Malaysia \\ E-mail address: tschin@mmu.edu.my
}

Received date: 6 Mai 2021; Accepted date:22 June 2021; Published date: 24 September 2021

Academic Editor: Sivan Rajah

Copyright (C) 2021. Susan Tee Suan CHIN. Distributed under Creative Commons Attribution 4.0International CC-BY 4.0

\begin{abstract}
The fifth industrial revolution brings in massive advantages, providing candidates with a more personalized experience in their job search. Industry 5.0 recognizes the power of industry in achieving societal goals beyond jobs and growth to become a resilient provider of prosperity by directing production towards respecting the boundaries of our planet and placing the wellbeing of the industry worker at the center of the production process. Contrary to the trends in Industry 4.0 toward technology, dehumanization, technological advancement and innovation best practices, Industry 5.0 will bend back toward serving humanity. At workplaces, this industrial revolution will shed greater light on the human intelligence than ever. The challenge now is to examine the influence of soft skills to enhance the workforce in order to prepare them for Industry 5.0. Emotional intelligence is a soft skill. The purpose of this study is to examine the influence of emotional intelligence on enhancing the workforce for Industry 5.0. A total of 110 executives took part in this study. Findings suggest that emotional intelligence does influence the workforce to perform better. Emotional recognition and expression and emotions direct cognition were found to have a greater impact on the performance.
\end{abstract}

Keywords: Performance; Competitive Advantage; Sustainability; Future; Profits

\section{Introduction}

Staying at the top is getting tougher and more challenging due to the fast-growing and changing digital technologies. The world of technology, mass customization, and advanced manufacturing is experiencing a rapid transformation. A strong necessity to increase productivity while keeping human workers in the manufacturing industry is imposing challenges on the global economy (Nahavandi, 2019). The concept of human

Cite this Article as: Susan Tee Suan CHIN (2021)," Influence of Emotional Intelligence on the Workforce for Industry 5.0", Journal of Human Resources Management Research, Vol. 2021 (2021), Article ID 882278, DOI: $10.5171 / 2021.882278$ 
and machines working in tandem could be possible if the concept is seen from two aspects (Arivarasu, 2019). Robots can be used for repetitive, labour-intensive or dangerous work, while humans can be deployed for customisation and for thinking critically and radically in and out of the box. There are 3 main challenges within Industry 5.0 (Cojocariu, 2021), namely skills, technology and investment. The adoption of a new technology requires not only time and effort but also investment. The main challenge comes from the people who have to be equipped with both the necessary technical and soft skills. There is a need to focus on sustainability, productivity and human efficiency. The purpose of this paper is to look into the requirements needed from the people involved in Industry 4.0 to be able to shift to Industry 5.0.

\section{Literature Review}

There are four historic industrial revolutions that show where the manufacturing industry is headed and what would differentiate the next one 'Industry 5.0', taking shape over the next two decades (Arivrasu, 2019).

Industry 1.0: The first industrial revolution began in the 1700s with the introduction of engines powered by water, steam, and coal, which moved the economy away from agriculture to industrial production, paving the way for the first factories. Industry 2.0: By the 1870s, industrialization had moved on to the second revolution with the use of newfound energy resources such as oil, electricity, and gas. Industry 2.0 gained momentum with the electrification of the assembly lines for mass production. This period was revolutionized with the invention of the telegraph and the telephone, which made long-distance communications possible. Industry 3.0: Almost a century later, in the 1970s, industrialists began to use electronics and computers in manufacturing. The third industrial revolution made use of microprocessors, information technology, and robots for a high level of automation in production. Soon, there was a surge in globalization and manufacturing outsourcing due to the availability of skilled labor and lower production costs. Industry 4.0: The fourth industrial revolution, dubbed as the 'information revolution,' introduced the concept of digitalization and integrated it into manufacturing. The advent of connected devices and technologies such as CyberPhysical Systems (CPS), Industrial Internet of Things (IIoT), data analytics, cloud computing, cybersecurity, big data, and Artificial Intelligence (AI) made the factories much more efficient and smarter.

Japan has defined Industry 5.0 as 'Society 5.0' or a 'human touch' revolution, defining it as: "A human-centered society that balances the economic advancement with the resolution of social problems by a system that highly integrates cyberspace and physical space". The phenomenon visualizes a forwardlooking society without information stagnation. Technical skills will be far less important in the future, with personal skills becoming more critical (Mohd \& Abid, 2020). These personal skills are referred to as soft skills. Soft skills enhance the workforce (Neves, 2021). In addition to technology, digital, and data acumen, soft skills are also going to be increasingly in demand (Moran, 2019). Soft skills include the art of communication and also the ability to think in a creative and critical manner.

\section{Emotional Intelligence - Soft Skills}

Research revealed that Emotional Intelligence (EI) helps to effectively solve complex, atypical problems that can hardly be solved even by robots; it also enables looking at particular issues from different viewpoints, to interact and co-operate in an intercultural team, to think independently and critically, and to persuasively communicate and represent (Delfi, 2019). The Resource Based View model suggests that the capabilities of the organisation comprises of the set of competencies, skills and abilities which coordinates the sets of tasks to achieve the goals set by the

Susan Tee Suan CHIN, Journal of Human Resources Management Research, DOI: $10.5171 / 2021.882278$ 
management (de Castro Moura Duarte, Brito, Di Serio \& Martins, 2011).

According to the Genos Emotional Intelligence (previously named as Swinburne University Emotional Intelligence Unit), there are five key emotional competencies that can be used in a workplace environment (Palmer \& Stough, 2001)

1- "Emotional Recognition and Expression" - refers to the employees' ability to determine their own sensitivity and emotive states and the power to express their inner feelings to their fellow colleagues at the workplace.

2- "Understanding Others' Emotions" refers to the employees' ability to determine and comprehend the sensitivity of their fellow colleagues and those that manifest in response to workplace environments and staff meetings.

3- "Emotions Direct Cognition" - refers to the point to which feelings and affectional cognition are integrated in decision-making and problem solving situations.

4- "Emotional Management" - pertain to the power to manage positive and negative emotions both within oneself and others.

5- "Emotional Control" - pertain to the ability to effectively control strong emotional states experienced at work such as anger, stress, anxiety and frustration.

\section{Methodology}

For the purpose of this study, Malaysian companies, who are involved in Industry 4.0 projects initiated by the Ministry of Investment Development and Authority (MIDA), will be the target population. In Malaysia, these investment areas are termed as Smart Investment Centers or known as SIC (NST, 2017). These investment centers include Penang, Selangor and Melaka. In this study, a particular plastic manufacturing organisation was chosen as it is one of the oldest and most successful plastic manufacturing organisations in Malaysia (Mordor Intelligence, 2021). The organisation started its operations in 1963. Back then, the organisation had 2 employees only. Currently, the organisation has around 1000 employees and branches in Penang, Selangor and Melaka. A total of 110 employees, from this organization, participated in the survey. 2 sets of questionnaires were distributed to these employees. The questionnaires comprised the statements on Emotional Intelligence (developed by Palmer \& Stough, 2001) and Organisational Performance (developed by Zulkifli \& Perera, 2011).

As can be seen in Table 1, the majority of the executives are Males (63.6\%) and $54.55 \%$ of them are more than 40 years old. $58.18 \%$ of them have worked in the organisation for more than 10 years. This is an indication that most of them are loyal to the organisation. Loyalty is an important element in the workforce. Since this is a manufacturing organisation, $70 \%$ of the workforce are in various areas which are directly related to production, for example, Engineering, Store and Logistics.

Susan Tee Suan CHIN, Journal of Human Resources Management Research, DOI: $10.5171 / 2021.882278$ 
Table 1: Analysis of the Respondents

\begin{tabular}{|c|c|c|c|c|}
\hline & & Frequency & Percentage & $\begin{array}{l}\text { Cumulative } \\
\text { Percentage }\end{array}$ \\
\hline \multirow[t]{2}{*}{ Gender } & Male & 70 & & 63.6 \\
\hline & Female & 40 & 46.40 & 100.0 \\
\hline \multirow[t]{5}{*}{ Age Group } & Less than 30 years old & 2 & & 1.82 \\
\hline & $\begin{array}{l}\text { More than } 31 \text { but less than } 35 \\
\text { years old }\end{array}$ & 18 & 16.36 & 18.18 \\
\hline & $\begin{array}{l}\text { More than } 36 \text { but less than } 40 \\
\text { years old }\end{array}$ & 30 & 27.27 & 45.45 \\
\hline & $\begin{array}{l}\text { More than } 41 \text { but less than } 45 \\
\text { years old }\end{array}$ & 40 & 36.36 & 81.81 \\
\hline & More than 46 years old & 20 & 18.19 & 100.0 \\
\hline \multirow[t]{2}{*}{ Nationality } & Malaysian & 104 & & 94.54 \\
\hline & Non-Malaysian (China) & 6 & 5.46 & 100.0 \\
\hline \multirow[t]{2}{*}{\begin{tabular}{|l} 
Marital \\
Status \\
\end{tabular}} & Single & 6 & & 5.46 \\
\hline & Married & 104 & 94.54 & 100.0 \\
\hline \multirow[t]{6}{*}{ Department } & $\begin{array}{l}\text { Human Resource and } \\
\text { Administration }\end{array}$ & 21 & & 19.09 \\
\hline & Finance and Accounts & 12 & 10.91 & 30.00 \\
\hline & Production & 21 & 19.09 & 49.09 \\
\hline & Sales and Marketing & 20 & 18.18 & 67.27 \\
\hline & Engineering & 30 & 27.27 & 94.54 \\
\hline & Store and Logistics & 6 & 5.46 & 100.0 \\
\hline \multirow[t]{4}{*}{\begin{tabular}{|l} 
Education \\
Level \\
\end{tabular}} & Diploma and Lower & 48 & & 43.64 \\
\hline & Bachelors' Degree & 58 & 52.73 & 96.37 \\
\hline & Masters Degree & 2 & 1.82 & 98.19 \\
\hline & Professional Qualification & 2 & 1.81 & 100.0 \\
\hline \multirow[t]{4}{*}{\begin{tabular}{|l|} 
Length of \\
Employment \\
\end{tabular}} & Less than 2 years & 4 & & 3.64 \\
\hline & $\begin{array}{l}\text { More than } 2 \text { but less than } 5 \\
\text { years }\end{array}$ & 12 & 10.91 & 14.55 \\
\hline & More than 5 but less than 10 & 30 & 27.27 & 41.82 \\
\hline & More than 10 years & 64 & 58.18 & 100.0 \\
\hline
\end{tabular}

\section{Findings and Discussion}

The $\mathrm{R}$ square is 0.657 , which means that $65.7 \%$ of the variations in the Organisational Performance were attributed to the dimensions of Emotional Intelligence (see Table 2). The above average percentage showed that Emotional Intelligence does have an impact on the performance of the organisation. 
Table 2: Model Summary between the dimensions of Emotional Intelligence and Organisational Performance

\begin{tabular}{|c|c|c|c|c|}
\hline Model & R & R Square & $\begin{array}{c}\text { Adjusted R } \\
\text { Square }\end{array}$ & $\begin{array}{c}\text { Std Error of } \\
\text { the Estimate }\end{array}$ \\
\hline & $.811 \mathrm{a}$ & .657 & .641 & .41879 \\
\hline
\end{tabular}

Using the hierarchical multiple regression analysis, it can be seen that understanding others emotions has a $\mathrm{p}$ value which is more than 0.05 . The remaining four emotional competencies, which are emotional recognition and expression, emotions direct cognition, emotional management and emotional control, have $\mathrm{p}$ values which are less than 0.05. These four emotional competencies were found to have a significant positive relationship with organisational performance (see Table 3).

Table 3: Coefficient Analysis between the dimensions of Emotional Intelligence and Organisational Performance

\begin{tabular}{|c|c|c|c|c|c|c|}
\hline \multirow[t]{2}{*}{ Model } & & \multicolumn{2}{|c|}{$\begin{array}{l}\text { Unstandardised } \\
\text { Coefficients }\end{array}$} & \multirow{2}{*}{$\begin{array}{c}\begin{array}{c}\text { Standardis } \\
\text { ed } \\
\text { Coefficient } \\
\text { s }\end{array} \\
\text { Beta }\end{array}$} & \multirow[t]{2}{*}{ t } & \multirow[t]{2}{*}{ Sig } \\
\hline & & $\bar{B}$ & Std Error & & & \\
\hline 1 & $\begin{array}{l}\text { (constan } \\
\text { t) }\end{array}$ & .023 & .331 & & .069 & .945 \\
\hline & ERE & .320 & .070 & .325 & 4.565 & .000 \\
\hline & UOE & .158 & .082 & .149 & 1.931 & .056 \\
\hline & EDC & .250 & .072 & .263 & 3.477 & .001 \\
\hline & EM & .164 & .076 & .168 & 2.155 & .033 \\
\hline & EC & .178 & .069 & .167 & 2.596 & .011 \\
\hline
\end{tabular}

Reference: ERE= Emotional Recognition and Expression; UOE = Understanding Others Expression; EDC = Emotions Direct Cognition; EM = Emotional Management; EC = Emotional Control

Two emotional competencies have a rather high t value, which are emotional recognition and expression and emotions direct cognition. $T$ values signify the impact of the variable on the dependent variable. From the analysis, emotional intelligence plays an important role in the performance of the organisation. Based on the results, as seen in Table 3, emotional recognition and expression, emotional management and emotional control (focusing more on interactive skills) and emotions direct cognition (focusing on the ability in problem solving situations) were found to have a positive and significant relationship with organisational performance.
Emotions direct cognition improves employees' decision making skills. Decisionmaking is a vital part of any business entity and it is a key function to the success of the organisation. While some employees may prefer factual decision making, some prefer using their gut feelings which is based on their years of experience. Making decisions that lead to successful results for the organisation makes employees look and feel good. This improves employees' leadership skills. Decision making does not allow for second guessing. A good employee must make the decision based on the available information and proceed with a quick and professional judgment. The future of the organisation depends on the decision made.

Susan Tee Suan CHIN, Journal of Human Resources Management Research, DOI: $10.5171 / 2021.882278$ 
Neves (2021) has suggested that soft skills strengthen the workforce. It is agreed that technical skills are important because technical knowledge enables employees to understand the technology applied. Soft skills are intangible qualities that harmonize the workplace environment through the art of communication and understanding one another (Forbes, 2019). For Industry 5.0, as suggested by Japan's approach as a "human centric approach", humans are working along with the technology. They need to be able to do things that robots are not able to do (Euronews, 2021). The Fifth Industrial Revolution will pair human and machine to further utilize human brainpower and creativity to increase process efficiency by combining workflows with intelligent systems. Based on the study, it is suggested that emotions direct cognition would enhance the decision making skills especially in improving the creativity and efficiency of the organisation.

\section{Conclusion and Areas of Future Study}

This study examines the properties of emotional intelligence and its relationship with the performance of the organisation. The findings suggested that 4 dimensions of emotional intelligence can be instrumental in strengthening the workforce during Industry 5.0. Industry 5.0 is said to be more human centric where humans and robots are working together in harmony. The employees will be able to contribute to the performance of the organisation in terms of their decision making abilities and also the art of communication. The art of communication focuses on workplace harmony. Employees need to be able to manage their emotions well especially during extreme situations. Based on the findings, emotional control and emotional management had a significant relationship with the performance of the organisation.

The study focused on a particular manufacturing industry. The findings may not relate to other manufacturing organisations in a different industry. It is highly recommended that for future studies, the study examines other manufacturing organisations in Malaysia. The study was made during Covid-19; hence the author was not able to administer the questionnaires to the executives in the organisation. The human resource personnel were entrusted to distribute and collect the questionnaires on behalf of the author. For future studies, it would be better if more organisations in the same industry take part in the study. Findings would enhance the knowledge in the subject matter.

\section{References}

- Arivarasu, S (2019) Role of Humans in Industry 5.0. Columbus. (Retrieved from:

https://www.columbusglobal.com/en/ blog/role-of-humans-in-industry-5.0.

Retrieved on May 3,2021)

- Cojocariu, O (2021) Industry 5.0 opportunities and challenges: bring your factory into the future.

Digitaya. (Retrieved from https://digitalya.co/blog/industry-5opportunities-and- challenges/.

Retrieved on May 3, 2021)

- de Castro Moura Duarte, A. L., Brito, L. A., Di Serio, L. C., \& Martins, G. S. (2011). Operational practices and financial performance: an empirical analysis of Brazilian manufacturing companies. Brazilian Administration Review, 8(4), 395- 411

- Delfi (2019) Scientists predict: AI and humans in the Industry 5.0. (Retrieved from

https://www.delfi.lt/en/business/scien tists-predict-ai-and-humans-in-theindustry-50.d?id=83095857)

- Euronews (2021) Japan's humancentred smart cities enhancing wellbeing. (Retrieved from https://www.euronews.com/2021/01/ 18/japan-s-human-centred-smartcities-enhancing- well-being) January 21, 2021

- Forbes (2019) What Are The Top 10 Soft Skills For The Future Of Work? (Retrieved from https://www.forbes.com/sites/adigask ell/2019/02/22/what-are-the-top-10-

Susan Tee Suan CHIN, Journal of Human Resources Management Research, DOI: $10.5171 / 2021.882278$ 
soft-skills-for- the-future-ofwork/?sh=160e98dc7f1f) February 22, 2019

- Mohd J. \& Abid, H (2020) Critical Components of Industry 5.0 Towards a Successful Adoption in the Field of Manufacturing. Journal of Industrial Integration and Management Vol. 05, No. 03, pp. 327-348 (2020)

- Moran, G (2019) Co-Exist With Robots: How to Compete With Technology in the Age of Automation. (Retrieved from :

https://fortune.com/2019/08/18/jobreplaced-by-automation-artificialintelligence-ai/)

- Mordor Intelligence (2021) Malaysia Plastics Market - Growth, Trends, Covid19 Impact, And Forecasts (2021 - 2026). (Retrieved from https://www.mordorintelligence.com/i ndustry-reports/malaysia-plasticsmarket. Retrieved on May 3, 2021)

- NST (2017) Top notch industries to participate in Industry 4.0 seminar. New Straits Times (August 14, 2017).
- Nahavandi, S (2019) Industry 5.0-A Human-Centric Solution, Institute for Intelligent Systems Research and Innovation, Deakin University, Waurn Ponds 3216, Australia. Sustainability 2019, 11(16), 4371; https://doi.org/10.3390/su11164371

- Neves, A (2021) 5 Skills You Need to Work on to Get Ahead-No Matter What Industry You're In. (Retrived from https://www.themuse.com/advice/5skills-you-need-to-work-on-toget-aheadno-matter-what-industryyoure-in. Retrieved on May 3, 2021).

- Palmer, B \& Stough, C (2001). Swinburne University Emotional Intelligence Test Interim Technical Manual. Melbourne: Swinburne University. 